The

Connecticut

Experiment

Balsam Twig Aphids

Station,

in Christmas Trees

New Haven

BY RICHARD S. COWLES

Bulletin 988

April 2003 
The Connecticut Agricultural Experiment Station (CAES) prohibits discrimination in all its programs and activities on the basis of race. color, ancestry, national origin, sex, religious creed, age, political beliefs, sexual orientation, criminal conviction record, genctic information, learning disability, present or past history of mental disability, mental retardation or physical disability including but not limited to blindness, or marital or family status. To file a complaint of discrimination, write Director, The Connecticut $\Lambda$ gricultural Experiment Station, P.O. Box 1106, New Haven. CT 06504, or call (203) 974-8440. CAES is an equal opportunity provider and employer. Persons with disabilities who require alternate means of communication of program information should contact the Station Editor il (203) 974-8446 (voicc); (203) 974-8502 (FAX); or paul.gough $(a$ po.state.ct.us (E-mail) 


\title{
Management of Balsam Twig Aphids in Christmas Trees
}

\author{
By Richard S. Cowles
}

The balsam twig aphid, Mindarus abietinus Koch, can be a serious pest of true firs (Abies spp.) grown for use as Christmas trees. The feeding of these aphids causes rapidly expanding shoots and their associated needles to curl. Besides the unsightliness of twisted foliage, large colonies of aphids developing in late spring and early summer excrete copious honeydew, which drips over the foliage and supports the growth of sooty mold fungi. Sooty mold is not a plant pathogen, but is an unsightly black coating, and can physically block sunlight and thereby interfere with plant functions such as photosynthesis. The current practice of Christmas tree growers is to spray true firs one or two times with insecticide, typically chlorpyrifos (Lorsban), each growing season to prevent this injury. These sprays, in turn, can adversely impact naturally occurring beneficial organisms that help to maintain low populations of other pests, such as spruce spider mites. Therefore, effective management of balsam twig aphid needs to take into account the effectiveness of insecticide treatments and the side effects of these sprays on non-target beneficial arthropods.

Life cycle. Small black eggs clothed in rods of a white wax overwinter on the bark of branches. Stem mothers, also called the fundatrices (fundatrix is the singular), hatch from these eggs and develop into wingless adults. The adult is pear-shaped and about as long as a fir needle is wide. The bluish-gray body has four indistinct longitudinal stripes of powdery white material, which is especially prominent on the head and thorax. The stem mother gives live birth to her young, which develop into either wingless fundagenae or winged sexuparae, which are all parthenogenic clones of the mother. The feeding of the stem mother and her offspring on succulent new growth causes the young needles to curl as they expand. This twisted growth forms a pseudogall in which the inwardly curving needles protect the rapidly reproducing colony of aphids from being dislodged by rain or wind. Sexuparae, which are all females, complete three molts and are winged as adults, allowing them to disperse from the tree on which they developed. Sexuparae have a distinctive arrangement of five dark spots on the thorax and four hardened sections of cuticle (sclerites) on the upper surface of their abdomens. Fundagenae and sexuparae produce the third generation, called sexuales, which consist of females and males. The sexuales physically resemble the sexuparae. This last generation of aphids, produced in the first half of June, mates and lays the overwintering eggs on the trees (Johnson and Lyon 1988).

Injury to Christmas trees principally is due to the distortion of needles resulting from the feeding of stem mothers and their offspring on rapidly expanding terminal growth. Development of overwintered balsam twig aphid eggs is closely synchronized with the growth of their principal host: nearly all of these eggs hatch by the time that $50 \%$ of balsam fir trees have broken new growth. So, although balsam twig aphids can develop on other hosts (all firs, white and Colorado spruce, and juniper), the close synchrony of this aphid's development with balsam fir bud break makes it especially damaging to this species.

However, poor control of aphid stem mothers on balsam fir can lead to damage on nearby Fraser and Canaan firs. In this scenario, the rapid dispersal of the winged sexuparae from balsam fir can coincide with bud break on Fraser or Canaan firs, leading to aphid colony establishment and damage.

The economic loss to Christmas tree growers from balsam twig aphids arises from several factors. First, aesthetic damage, both from twisting of terminals and from sooty mold, may reduce the value of trees. This is particularly true for trees being produced for wholesale marketing, where purchasers are wary of aesthetic injury. Surprisingly, choose-and-cut customers do not usually object to (or even notice) balsam twig aphid injury, and therefore insecticide treatments may not be warranted for this clientele (Kleintjes et al. 1999). Secondly, economic loss can result from the expenses of applying insecticides to control this pest and all the additional costs associated with secondary 
pest outbreaks. These pest outbreaks happen when the insecticides used to control balsam twig aphids kill beneficial insects or mites, which may have been keeping other pests in check. Outbreaks of spruce spider mite can be especially costly to control.

\section{MANAGEMENT OPTIONS}

Cultural control. One approach to minimize damage by this insect is to grow other species of fir, such as Fraser fir or the balsam-Fraser hybrid, the Canaan fir. It is unknown whether balsam twig aphids avoid laying eggs on these species, or whether the long time between aphid hatch and availability of new growth on these late-breaking firs causes high mortality in stem mothers. In any case, there is generally much less damage to firs with late bud break characteristics than to balsam fir. However, as mentioned previously, winged aphids can migrate from balsam fir to cause severe infestations on nearby plantings of other firs.

Biological control. Many arthropods are avid predators of balsam twig aphids. For example, surveys of balsam twig aphid populations in 2000-2002 revealed very high populations of the multicolored Asian ladybeetle (Harmonia axyridis), lacewing larvae, syrphid larvae, whirlygig mites (Anystis spp.), and parasitic wasps feeding on these aphids. Although these predators and parasites may not build up fast enough to prevent twisting of foliage, their activity reduces the overall aphid population and decreases the number of overwintering eggs laid later in the summer. Therefore, an important objective for managing balsam twig aphid should be to conserve predators and parasites. Healthy populations of beneficial arthropods provide a natural mechanism for aphid population reduction, which is especially needed where chemical control has been inadequate.

Chemical control. Use of insecticides, especially chlorpyrifos (Lorsban), has been the mainstay for managing balsam twig aphid populations in Christmas trees for several years. Chlorpyrifos has the unusual property of converting directly from a solid to a gas, allowing it to fumigate the plantation (Fritt 1993). Its ability to penetrate areas not covered by spray deposit has made it the material of choice for use with mist blower sprayers, permitting rapid spraying of plantings. However, chlorpyrifos is an organophosphate insecticide and is moderately to highly toxic to humans, birds, fish, and beneficial arthropods (ace.orst.edu). As an organophosphate insecticide, it continues to undergo review by the U.S. Environmental Protection Agency and has already had some uses removed from its label. Growers in the South Windsor area experienced poor control of balsam twig aphid following two applications of chlorpyrifos to plantings in 2002, suggesting that local populations of these aphids may be resistant to this insecticide. Therefore, alternatives to the use of chlorpyrifos need to be tested to determine how well they can perform in suppressing balsam twig aphid populations in Christmas tree plantations.

Aphid control field experiments. These studies were conducted at cooperating growers' fields to determine the most effective insecticides for control of balsam twig aphid. High and low volume spray application was used to determine which insecticides are appropriate for different kinds of spray equipment. Because there were many aphid predators observed during the test in 2000 , the predator populations were measured along with the twig aphids in the second year to determine which insecticides selectively killed the aphids rather than their predators.

High-volume spray and soil-applied systemic experiment. This experiment was conducted at a cooperating grower's field in Somers, with balsam fir planted in a $5 \times 6$ foot pattern. Plots consisted of a $4 \times 4$ array of trees, plus a buffer row along all sides. There were four replicates in a randomized complete block design. Materials used in foliar sprays included pymetrozine (Endeavor 50W, Syngenta, Greensboro, NC), thiamethoxam (Flagship 25W, Syngenta), horticultural oil (Lesco Horticultural Oil, Lesco, Strongsville, $\mathrm{OH}$ ), chlorpyrifos (Lorsban 4E, Dow AgroSciences, Indianapolis, IN), insecticidal soap (Olympic, Bradenton, FL), acephate (Orthene 70S, Valent, Walnut Creek, CA), and endosulfan (Thiodan 3E, FMC, Philadelphia, PA). For products needing a surfactant, Silwet L-77 (Helena, Memphis, TN) was added, and it was also included by itself as a control. Imidacloprid (Provado 1.6F, Bayer, St. Louis, MO) was applied in the fall or spring to the soil for systemic uptake, or in the spring as a foliar spray. A backpack sprayer equipped with a TK-2 floodjet nozzle (Spraying Systems, Wheaton, IL) was used on October 20, 1999, for the liquid broadcast application in a spray volume of 40 gallons per acre. To guarantee soil incorporation, this application was made during a rain event of 0.5 inches. Due to dry spring conditions, a Kioritz injector was used for the March 31, 2000, soil incorporation. Six 5-ml injections were placed along the dripline for each tree at a depth of 2 inches. Foliar sprays were applied on two days, April 25 and 26, 2000 , when balsam fir had reached $50 \%$ bud break. A hydraulic sprayer applied 435 gallons per acre. Conditions on April 25 were $60 \mathrm{~F}$, sunny and dry. Conditions on April 26 were $40 \mathrm{~F}$, with wet snow changing to rain. Populations of stem mothers were assessed on May 3, with four beating samples from each of four trees in each plot. The beating tray was a pad $(8.5 \times 1]$ inches) of white paper on a clipboard. At this date, stem mothers had begun producing young, which were too small to count. Plots were evaluated again on June 13-14 by counting alate (winged) aphids with beating samples and counting the percent of damaged terminals (from a sample of 50 terminals on each of four trees per plot). Data were subjected to analysis of variance.

Chlorpyrifos, insecticidal soap, thiamethoxam, the imidacloprid foliar spray, oil, and acephate all gave excellent early-season control (> $95 \%$ mortality) of fundatrix aphids 
Table 1. Control of balsam twig aphid with a high-volume spray (435 gallons per acre) and soil applied systemic insecticide application, $n=4$.

\begin{tabular}{|c|c|c|c|c|c|c|c|}
\hline \multirow[b]{2}{*}{ Product } & \multirow[b]{2}{*}{ Chemical name } & \multirow[b]{2}{*}{ Use rate } & \multirow[b]{2}{*}{ Application type } & \multicolumn{2}{|c|}{ Aphid count } & \multirow{2}{*}{$\begin{array}{l}\text { Control } \% \\
5 / 3\end{array}$} & \multirow{2}{*}{$\begin{array}{l}\text { Damaged } \\
\text { terminals \% }\end{array}$} \\
\hline & & & & $5 / 3$ & $6 / 13-14$ & & \\
\hline Endeavor $50 \mathrm{~W}$ & pymetrozine & $0.1 \mathrm{lb}$ a. i. $/ \mathrm{Ac}$ & spring foliar spray & $6.3 \mathrm{~d}$ & $20 a b$ & 89 & $15 \mathrm{bc}$ \\
\hline $\begin{array}{l}\text { Flagship } 25 \mathrm{~W} \\
+ \text { Silwet L-77 }\end{array}$ & thiamethoxam & $0.1 \mathrm{lb}$ a. i. $/ \mathrm{Ac}$ & spring foliar spray & $1.0 \mathrm{~d}$ & $3.8 \mathrm{ab}$ & 98.3 & $3.1 \mathrm{c}$ \\
\hline Lesco Oil & oil & $2 \%$ & spring foliar spray & $1.3 \mathrm{~d}$ & $21 \mathrm{a}$ & 98 & $11 b c$ \\
\hline Lorsban 4E & chlorpyrifos & $8 \mathrm{fl} \mathrm{oz} / 100 \mathrm{gal}$ & spring foliar spray & $0.3 \mathrm{~d}$ & $21 \mathrm{a}$ & 99.6 & $6.3 \mathrm{c}$ \\
\hline $\begin{array}{l}\text { Olympic Insecticidal } \\
\text { Soap }\end{array}$ & insecticidal soap & $2 \%$ & spring foliar spray & $0.3 \mathrm{~d}$ & $21 \mathrm{a}$ & 99.6 & $7.4 \mathrm{c}$ \\
\hline Orthene $75 \mathrm{~S}$ & acephate & $1 \mathrm{lb}$ a.i. $/ \mathrm{Ac}$ & spring foliar spray & $3.0 \mathrm{~d}$ & $10 \mathrm{ab}$ & 95 & $21 b c$ \\
\hline Provado $1.6 \mathrm{~F}$ & imidacloprid & $0.4 \mathrm{lb}$ a. i. $/ \mathrm{Ac}$ & fall broadcast & $45 \mathrm{ab}$ & $4.8 \mathrm{ab}$ & 23 & $31 \mathrm{bc}$ \\
\hline Provado 1.6F & imidacloprid & $0.4 \mathrm{lb}$ a. i. $/ \mathrm{Ac}$ & spring soil injection & $30 \mathrm{bc}$ & $0.8 \mathrm{~b}$ & 50 & $21 b c$ \\
\hline $\begin{array}{l}\text { Provado } 1.6 \mathrm{~F} \\
+ \text { Silwet L-77 }\end{array}$ & imidacloprid & $8 \mathrm{fl} \mathrm{oz} / \mathrm{Ac}$ & spring foliar spray & $1.0 \mathrm{~d}$ & $11 a b$ & 98.3 & $2.4 \mathrm{c}$ \\
\hline Thiodan 3E & endosulfan & $21 \mathrm{fl} \mathrm{oz} / 100 \mathrm{gal}$ & spring foliar spray & $24 b$ & $9.3 \mathrm{ab}$ & 59 & $37 \mathrm{~b}$ \\
\hline Silwet L-77 & surfactant & $4 \mathrm{fl} \mathrm{oz} / 100 \mathrm{gal}$ & spring foliar spray & $27 b c$ & $5.5 \mathrm{ab}$ & 54 & $37 \mathrm{~b}$ \\
\hline Untreated check & & & & $59 \mathrm{a}$ & $3.5 \mathrm{ab}$ & - & $57 a$ \\
\hline
\end{tabular}

${ }^{a}$ Means in each column followed by the same letter are not significantly different, $P=0.05$, Newman-Keul's test applied to square root $(x+0.5)$ transformed counts of aphids.

(Table 1). The later evaluation of aphid populations and percent terminal curling revealed some interesting phenomena. First, curling and twisting of foliage occurs only in response to feeding from the early-season aphid populations. This is evident from the strongly correlated $(r=0.74)$ May 3 aphid counts and percent shoot damage. Secondly, the population of the aphids in June was approximately inversely proportional to the populations observed in early May. In other words, treatments with high counts in May tended to have low counts in June and vice versa. This is probably explained by (1) the exploitation of aphids by predators and parasites, and (2) migration of winged aphids from heavily infested trees. It is striking that trees did not maintain high populations of aphids throughout the trial. Predators and parasites can be credited with responding to aphid colonies efficiently enough to prevent trees from remaining heavily infested for more than a few weeks. For example, on the untreated check trees, the population fell from averages of 59 to 3.5 aphids over 40 days. Unfortunately, predators did not reduce aphid populations quickly enough to prevent damage during the critical few weeks while shoots were rapidly growing. Treatments resulting in a shift from low counts in May to high counts in June (Endeavor, oil, Lorsban, and insecticidal soap), demonstrate the ability of colonizing winged sexuparae to generate new colonies on trees from which aphids had previously been virtually eliminated (because of the earlier insecticide spray). In these instances, predators hadn't yet had time to find these colonies and reduce the aphid population.

Thiamethoxam was exceptional in its residual protection of trees. Besides providing early season control and protection from shoot distortion, thiamethoxam also generally prevented sexuparae from establishing new colonies. The excellent overall control results with thiamethoxam and imidacloprid suggest that other highly systemic and selective experimental aphicides, such as acetamiprid (Assail) and flonicamid, may be of value for balsam twig aphid management.

Preventing colony development after the period of shoot elongation may be indirectly beneficial by reducing the numbers of overwintering eggs being laid, which would influence the pest pressure in the following year. Endeavor, oil, Lorsban, and insecticidal soap permitted resurgence in the pest population. Pest resurgence in June could actually lead to worsening aphid populations from one year to the next. This scenario would only be likely where there are insecticide resistant aphids, populations are left untreated in the Christmas tree plantation, or populations on wild trees surrounding the farm re-infest the planting soon after spraying. In this experiment, use of small plots in a randomized complete block design virtually guaranteed 
rapid recolonization of trees by winged aphids emigrating from the untreated checks and ineffective treatments.

Imidacloprid applied to the soil in the spring was initially ineffective at reducing fundatrix populations, but was the only treatment that appeared to reduce the numbers of sexuparae and their progeny on Christmas trees in June relative to the untreated check. Therefore, imidacloprid applied as a soil treatment to control white grubs or balsam woolly adelgids might provide partial protection from the next year's population of fundatrices by limiting the lateseason population growth of aphids and by preventing egg laying on treated trees. This strategy, however, would have little value in providing reduction in shoot distortion during the year of application.

Low volume spray experiment. The most effective materials from the 2000 trials were included in a further low-volume application test using a backpack mist blower sprayer. Insecticidal soap and oil were not included because these materials are known to require a high spray volume. There were six treatments in a randomized complete block design with six replicates. The block of balsam firs in Somers had not been sprayed with experimental insecticides in 2000, but had been sprayed with chlorpyrifos. An additional insecticide, triazamate (Aphistar 50W, Dow AgroSciences), was included in the test because it was being investigated for use on true firs for control of conifer root aphids, and was expected to have some activity against balsam twig aphids. Insecticides were applied in 20 gallons per acre of spray with a Solo backpack mist blower on May 3, 2001, under sunny $90 \mathrm{~F}$ conditions, and $0-10 \mathrm{mph}$ wind. Aphid counts were taken with beating samples conducted on May 10 and June 7, using the same method as in 2000. Populations of syrphid larvae, lacewing larvae, ladybeetle larvae and adults, and whirlygig mites (Anystis spp.) were counted from additional June 7 beating samples, using a 28 inch square canvas beating sheet (BioQuip Products, Gardena, CA). The beating sample was a composite from four trees, and four subsamples per tree. Damage ratings were taken on June 7 by visually rating the percent of terminal shoots that were damaged as category 0 (no damage), 1 (1-25\% curled), 2 (26-50\% curled), $3(51-75 \%$ curled) or 4 (76-100\% curled). Four samples of 20 shoots were evaluated and averaged for each plot.

Materials tested with low-volume spray application were not as effective as when they had been applied with the hydraulic sprayer. For example, Lorsban, Provado, Flagship and Endeavor provided 80, 85, 85 and $27 \%$ control

(Table 2), respectively, compared with $99.6,98,98$ and $89 \%$ control in the previous year. The poorer efficacy with the low-volume spray may also have been affected by the later spray timing. Trees and aphids grew very rapidly in 2001 in response to unseasonably hot weather, and the optimal timing for balsam twig aphid control had passed before these sprays were applied. Therefore, the spray in 2001 was directed at controlling colonies of stem mothers with young, rather than just the stem mothers. Surprisingly, this later timing was very effective in reducing foliar distortion, suggesting that spraying later than $50 \%$ bud break on balsam firs may be acceptable for managing these aphids. The most impressive result was the protection of Christmas trees from shoot damage with Aphistar, which gave significantly better control (95\% reduction on May 10) than the other treatments. On the other hand, Endeavor did not provide any significant benefit with the low volume spray.

Aphistar had the greatest impact on predator populations. Use of Aphistar significantly reduced the numbers of ladybeetles, lacewings and syrphid larvae (Table 3). As these are all aphid predators and there were few aphids remaining following use of this product, the predators may simply have starved or left due to the lack of food. Overall, the total numbers of predators did not differ among any of the treatments, because the increased numbers of Anystis (whirlygig mites) compensated for the reduction in the aphid specialist complex (Table 3 ). While not significantly different, there were numerically the most predators in the Aphistar-treated plots and the fewest in the Lorsban plots.

Balsam twig aphid management guidelines. Alternatives to chlorpyrifos with excellent activity against balsam twig aphid include insecticidal soap, horticultural oil, Aphistar, and Provado. The optimal choice of an insecticide will depend to a large extent on each grower's spraying equipment. Horticultural oil and insecticidal soap both require high volume application, so these materials are only compatible with hydraulic sprayers or small airblast sprayers that can fit between rows of Christmas trees. Insecticidal soap may be a less desirable choice because it is more costly than horticultural oil (1.15-3 times the price) and controls fewer pests and fewer stages. For example, fewer spider mite eggs are killed by soap than by oil (Osborne and Pettit 1985, Cowles and Abbey 1999). Some growers have been satisfied with horticultural oil, but this material can cause injury to balsam firs, characterized by browning and needle drop from the previous years' growth. Additional research will be necessary to determine whether oil's phytotoxicity to balsam firs can be avoided by adjusting the use rate, application timing, or by including adjuvants that will encourage better spreading of spray droplets and faster drying. Horticultural oil is especially valuable for use on Fraser firs, because they are more tolerant of oil and are also more susceptible to other pests (spruce spider mites and elongate hemlock scale) that can be controlled with oil. Horticultural oil can damage any plant material if it comes out of suspension in the spray tank, which can result in spraying undiluted oil. Mechanical agitation or addition of surfactants may be necessary to prevent separation.

The remaining insecticides, Aphistar and Provado, are 
Table 2. Control of balsam twig aphid with a low-volume spray applied with a backpack mist blower (20 gallons per acre), $n=6$.

\begin{tabular}{|c|c|c|c|c|c|c|}
\hline \multirow[b]{2}{*}{ Product } & \multirow[b]{2}{*}{ Chemical name } & \multirow[b]{2}{*}{ Rate/Acre } & \multicolumn{2}{|c|}{ Aphid count $\mathrm{t}^{\mathrm{a}}$} & \multirow{2}{*}{$\begin{array}{c}\text { Control }(\%) \\
\text { May } 10^{\mathrm{b}}\end{array}$} & \multirow{2}{*}{$\begin{array}{l}\text { Damage } \\
\text { Rating }^{c}\end{array}$} \\
\hline & & & May 10 & June 7 & & \\
\hline Lorsban 4E & chlorpyrifos & 16 fl. oz. & $21 b$ & $49 a$ & 80 & $1.0 \mathrm{~b}$ \\
\hline $\begin{array}{l}\text { Provado 1.6F } \\
+ \text { Silwet L-77 }\end{array}$ & imidacloprid & $\begin{array}{l}8 \text { fl. oz. } \\
4 \text { fl. oz. }\end{array}$ & $16 \mathrm{~b}$ & $40 \mathrm{ab}$ & 85 & $1.2 \mathrm{~b}$ \\
\hline $\begin{array}{l}\text { Flagship } 25 \mathrm{~W} \\
+ \text { Silwet L-77 }\end{array}$ & thiamethoxam & $\begin{array}{l}3 \mathrm{oz} . \\
4 \text { fl. oz. }\end{array}$ & $16 \mathrm{~b}$ & $34 \mathrm{ab}$ & 85 & $1.5 b$ \\
\hline $\begin{array}{l}\text { Aphistar 50W } \\
+ \text { Silwet L-77 }\end{array}$ & triazamate & $\begin{array}{l}8 \mathrm{oz} . \\
4 \mathrm{fl} . \mathrm{oz}\end{array}$ & $5 c$ & $11 \mathrm{c}$ & 95 & $0.0 \mathrm{c}$ \\
\hline $\begin{array}{l}\text { Endeavor } 50 \mathrm{~W} \\
+ \text { Silwet L-77 }\end{array}$ & pymetrozine & $\begin{array}{l}10 \mathrm{oz} . \\
4 \mathrm{fl.} \mathrm{oz} .\end{array}$ & $77 a$ & $22 b c$ & 27 & $3.2 \mathrm{a}$ \\
\hline Untreated check & & & $106 a$ & $25 b c$ & - & $3.2 \mathrm{a}$ \\
\hline
\end{tabular}

${ }^{a}$ Means in each column followed by the same letter are not significantly different, $P=0.05$, Newman-Keul's test applied to square root $(x+0.5)$ transformed counts of aphids.

${ }^{b}$ Percent control is relative to the population in the untreated check.

${ }^{\mathrm{c}}$ Damage rating is based on the percent damaged terminals: $0,0 \% ; 1,1-25 \% ; 2,26-50 \% ; 3,51-75 \% ; 4,76-100 \%$.

Table 3. Survival in percent of balsam twig aphid pregators with a low-volume spray applied with a backpack mist blower (20 gallons per acre), $n=6$.

\begin{tabular}{|c|c|c|c|c|c|c|}
\hline Product & Chemical name & Rate/Acre & $\begin{array}{l}\text { Lady } \\
\text { beetle }\end{array}$ & $\begin{array}{l}\text { Lace- } \\
\text { wing }\end{array}$ & Syrphids & $\begin{array}{r}\text { Whirlygig } \\
\text { mites }\end{array}$ \\
\hline Lorsban 4E & chlorpyrifos & $16 \mathrm{fl.} \mathrm{Oz.}$ & $31 \mathrm{a}$ & $1.5 b c$ & $12 a b$ & $6.3 \mathrm{a}$ \\
\hline $\begin{array}{l}\text { Provado } 1.6 \mathrm{~F} \\
+ \text { Silwet L-77 }\end{array}$ & imidacloprid & $\begin{array}{l}8 \text { fl. Oz. } \\
4 \text { fl. Oz. }\end{array}$ & $13 b$ & $4.3 \mathrm{ab}$ & $10 a b$ & $17 \mathrm{a}$ \\
\hline $\begin{array}{l}\text { Flagship } 25 \mathrm{~W} \\
+ \text { + Silwet L-77 }\end{array}$ & thiamethoxam & $\begin{array}{l}3 \mathrm{Oz} \\
4 \mathrm{fl} . \mathrm{Oz} .\end{array}$ & $25 \mathrm{a}$ & $1.8 \mathrm{bc}$ & $8.2 \mathrm{~b}$ & $23 a$ \\
\hline $\begin{array}{l}\text { Aphistar 50W } \\
+ \text { Silwet L-77 }\end{array}$ & triazamate & $\begin{array}{l}8 \mathrm{oz} . \\
4 \mathrm{fl} . \mathrm{Oz} .\end{array}$ & $4.5 \mathrm{c}$ & $0.2 \mathrm{c}$ & $3.0 \mathrm{c}$ & $28 \mathrm{a}$ \\
\hline $\begin{array}{l}\text { Endeavor 50W } \\
+ \text { Silwet L-77 }\end{array}$ & pymetrozine & $\begin{array}{l}10 \mathrm{fl} . \mathrm{Oz} . \\
4 \mathrm{fl} . \mathrm{Oz} .\end{array}$ & $6.7 \mathrm{a}$ & $15 a$ & $7.5 \mathrm{a}$ & \\
\hline Untreated check & & & $26 a$ & $2.8 \mathrm{ab}$ & $13 \mathrm{ab}$ & $18 a$ \\
\hline
\end{tabular}

${ }^{\text {a }}$ Means in each column followed by the same letter are not significantly different, $P=0.05$, Newman-Keul's test applied to square root $(x+0.5)$ transformed counts of predators.

appropriate for use with either low or high-volume spray equipment. Research in 2001 demonstrated that Provado + Silwet and Aphistar were effective with a low volume spray volumes (20 gallons per acre). Aphistar is only available under a Section 18, or Emergency Exemption, registration. Although this product is systemic, thorough spray coverage is still required to be effective. I have observed conspicuous failure of aphid control with Aphistar on the side of trees 
opposite the mist blower sprayer, a phenomenon called a "spray shadow." Combining Provado with an organosilicone surfactant (Silwet L-77, Kinetic, or CapSil 30) improves its effectiveness. For large Christmas tree plantations, the only practical way to quickly apply an even distribution of spray may be to use Aphistar or Provado + surfactant with a boom sprayer, with the spray boom passing over the tops of the trees. Other alternatives for improving spray distribution may be to remove the trees from the center row in each block to provide another drive row, to use a small sprayer that can fit between every row, or to adjust the space between rows at the time of planting to give additional drive rows for sprayers. A backpack mistblower could also be used to walk through and spot spray just those areas where coverage with the tractor-driven mistblower is inadequate.

Two areas need further research for improving management of balsam twig aphids: investigation into management of the egg laying sexuales and improved integration of chemical, cultural and biological control. Interfering with the egg laying activity of sexuales, either with insecticides or repellents, could provide a new control strategy. Until recently, the residual activity of most systemic insecticides was too short to affect multiple generations of aphids. Neonicotinyl compounds, however, can control sucking insect pests over several months when used as a soil-applied systemic (Varela et al. 1996, Cowles and Cheah 2002). It is especially intriguing that spring application of imidacloprid reduced the populations of sexuparae on trees (Table 1). Application of this systemic insecticide (or similar materials, like thiamethoxam) to the soil for control of white grubs or balsam woolly adelgid may control the sexuparae and sexuales generations, and may prevent balsam twig aphid injury in the following year by reducing the numbers of overwintering eggs (Kleintjes 1997). Dramatic reduction in egg laying could lead to a reduced need for a spring application of insecticides and improved chances that biological control would be sufficient for springtime aphid population suppression.

The common practice of yearly application of insecticides to manage balsam twig aphids in all true fir plantings is not warranted by customer preferences and economic risk. Scouting and threshold-based treatment guidelines could go far toward reducing unnecessary spraying for this pest (Kleintjes et al. 1999). The percent of damaged shoots can sometimes be correlated with counts of stem mothers determined from beating samples taken at bud break (Kleintjes et al. 1999). If the estimated population of stem mothers can be used to predict the percent shoot damage, then treatment decisions can be based on this information, whether the threshold used is relatively low (for wholesale-marketed trees) or higher (for choose-and-cut marketing).
Further advances in balsam twig aphid management will require integration of biological, cultural, and chemical control to stabilize aphid populations at non-economic population levels. Key to this effort will be clarification of the seasonal population dynamics of the aphid predators and parasitoids, with a special focus on improving the establishment and success of the beneficial species active at the same time as the fundatrix generation. Harmonia axyridis, the multicolored Asian ladybeetle, and Anystis mites were especially common and active, and would be good prospects. The balsam twig aphids have a short season of activity, so ground covers that support other species of aphids could in turn support these predators further through the growing season and increase their overwintering populations. Further investigations should optimize the use of selective aphicides so that they would only be used at times when there is a risk that aphid populations are great enough relative to predator populations to risk economic damage.

\section{REFERENCES}

Cowles, R.S. and T.M. Abbey. 1999. Of mites and men. Amer. Nurseryman 190(4): 68-77.

Cowles, R.S. and CAS-J Cheah. 2002. Systemic control of hemlock woolly adelgid, 1999. Arthropod Management Tests 27- G47.

Fritt, J.R. 1993. The benefit of fumigant action of chloropyrifos for control of cotton aphid. Down to Earth 48(2): 8-12.

Johnson, W.T. and H.H. Lyon. 1988. Insects that feed on trees and shrubs. Cornell University Press. Ithaca, NY.

Kleintjes, P.K. 1997. Midseason insecticide treatment of balsam twig aphids (Homoptera: Aphididae) and their aphidophagous predators in a Wisconsin Christmas tree plantation. Environ. Entomol. 26: 1393-1397.

Kleintjes, P.K., E.E. LeMoine, J. Schroeder, and M.J. Solensky. 1999. Comparison of methods for monitoring Mindarus abietimus (Homoptera: Aphididae) and their potential damage in Christmas tree plantations. J. Econ. Entomol. 92: 638-643.

Osborne, L.S. and F.L. Petitt. 1985. Insecticidal soap and the predatory mite, Phytoseiulus persimilis (Acari: Phytoseiidae), used in management of the twospotted spider mite (Acari: Tetranychidae) on greenhouse grown foliage plants. J. Econ. Entomol. 78: 687-691.

Varela, L.G., R.S. Cowles, and D.R. Donaldson. 1996. Spring insecticide treatments control adelgids on Douglasfir. California Agriculture 50 (5): 34-37. 


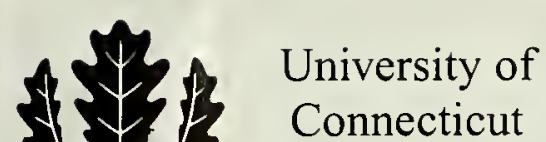 14. conersian Libraries}

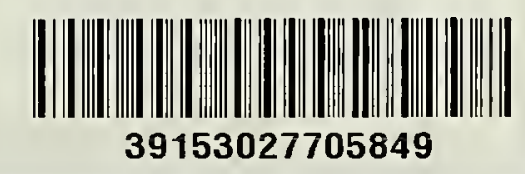


